\title{
Underpricing of initial public offerings in hot and cold markets: An empirical study on Borsa Istanbul
}

\author{
Ezgi TUNCAY, Mehmet KARAN, Eren MISKI AYDIN \\ Hacettepe University, Ankara, Turkey
}

\begin{abstract}
:
Aim: The performance of the initial public offerings is one of the most discussed anomalies in financial literature. The study aims to evaluate the initial public offering performance of Borsa Istanbul companies during the hot and cold periods. The size of the companies, industry concentration and investor optimism are considered in this respect.

Design / Research methods: The study covers the 119 IPOs of various sizes from different industries between 2010 and 2017 just after the global financial crisis. The standard event study methodology is applied. This study has revealed the existence of post-crisis underpricing effects in Turkey.

Conclusions/findings: The research shows that although low pricing is valid in hot periods, hot and cold markets do not differ significantly from each other in this context. Besides, this study finds that the low price effect exists for small firms, and this effect is more common in hot markets. On the other hand, although there is a relationship between consumer confidence index and low price, no relation with industry concentration was found
\end{abstract}

Originality/value of the article: This study has reported the IPO performance in Borsa Istanbul, an important emerging market, after the 2008 crisis, taking into account various market characteristics. This study provides practical results for the capital market players and institutions.

Implications of the research: The study will guide Borsa Istanbul's new companies to have successful public openings and international investors, which pursue market timing along with the financial institutions and policymakers

Limitations of the research: Subsequent studies may include variables such as corporate characteristics, financial performance, firm age and region, and corporate governance.

Keywords: Emerging market, Anomaly, Underpricing, Initial Public Offerings, hot and cold markets. JEL: $G 14 ; G 24 ; G 32$

\footnotetext{
Correspondence address: Ezgi TUNCAY, Haceteppe University, Ankara, Turkey. E-mail: ezgituncay@ymail.com (Ezgi TUNCAY), mbkaran@hacettepe.edu.tr (Mehmet KARAN), erenma@hacettepe.edu.tr (Eren MISKI AYDIN).

Received: 29.01.2020, Revised: 12.02.2020, Accepted: 12.02.2020-

doi: http://dx.doi.org/10.29015/cerem.871
} 


\section{Ezgi TUNCAY, Mehmet KARAN, Eren MISKI AYDIN}

\section{Introduction}

Market anomalies, which are cross-sectional and time-series patterns in the returns of securities that cannot be estimated by the classical finance theories (Keim 2008), are regarded as the beginning of the behavior approach in finance studies. The discovery of market anomalies is one of the milestones that open the discussion on the insufficiency of CAPM and efficient market hypothesis. Depending on empirical researches since the 1980s, the studies have increasingly attempted to explain the causes of these anomalies, revealing the inadequacies of classical finance theories. Mispricing (Lakonishok et al. 1994), unmeasured risk (Fama, French 1993), limits to arbitrage (Novy-Marx, Velikov 2015), and selection bias (McLean, Pontiff 2016) are the commonly witnessed concepts that try to elucidate them. Studies have shown that behavioral factors are relatively critical in investment decisions such that market players consider not only statistical and mathematical measures but also psychological factors such as sentiment, overconfidence, and overreaction (Kahneman et al. 1982). The current study addresses the underprice phenomenon of initial public offerings (IPO), which is considered as one of the anomalies of market efficiency. It is observed in primary markets worldwide, but the degree of return and significance depends on various factors.

IPO literature has been enriched and developed with new theories and hypotheses in the last decades. It covers not only the efficiency of the market studies but also the timing of initial offerings. In terms of investors, IPOs are usually a profitable timing opportunity in inefficient markets. These markets will enable them to exploit the information and obtain abnormal returns. Furthermore, the measurement of IPO performance in hot and cold markets plays an essential role in the studies focusing on timing.

The hot and cold market issue is based on the cyclical pattern of average initial returns over time. The early study of Ibbotson and Jaffe (1975) presents this cyclical pattern, suggesting the existence of the "hot issue market." Hot markets have been described as having a high volume of initial public offerings, severe underpricing, frequent oversubscription of offerings, and concentration in particular industries 
(Ritter 1984). On the other hand, a cold market will evolve at the end of the hot period, where unnatural low initial returns will tend to occur.

Related literature suggests a diversity of opinions on how hot and cold market firms might differ in IPO performance. Early studies on IPOs are inspired by a hypothesis which states that underpricing is a signaling mechanism and describes hot markets as periods when a significant number of high-quality firms choose to go public (Allen, Faulhauber 1989; Welch 1989). However, as the studies on this area have improved in recent years, various findings and hypotheses have emerged, explaining the underpricing effect in hot markets. The reviews of Chalk and Peavy (1987) and Ibbotson et al. (1994) on U.S. markets indicate that the underpricing phenomenon is more common in generally smaller sized IPOs. On the other hand, the Asymmetric Information and Signalling Hypothesis argue that reputable and high-quality companies will go public during a hot market; hence underpricing signals may indicate quality (Stoughton et al. 2001). Foreign funds that are the leading players of those markets consider larger companies as more reputable and keep relatively more shares of large firms and other firms with greater recognition or visibility in international markets (Kang, 1997; Dahlquist, Robertsson 2001). For this reason, it is necessary to illuminate whether the underprice anomaly will be prevailing for smaller or larger IPOs in emerging markets, such as Borsa Istanbul.

Furthermore, the Market Timing and Investor Sentiment Hypothesis (Lee et al. 1991; Baker, Wurgler 2000; Ljungqvist et al. 2005) and the Sequential Learning, Informational Externality and Industry Concentration Hypothesis and the Demand for Capital Hypothesis (Persons, Warther 1997; Subrahmanyam, Titman 1999) put forward noticeable arguments on the underpricing issue. The first hypothesis indicates that investors' optimism and confidence in the market results in an underpricing effect in initial public offerings. The second one reveals that the underpricing phenomenon of IPOs tends to be aggregated around similar industries (Jenkinson, Ljungqvist 2001). Investors and stock market institutions tend to choose the information externality created by the outcomes of previous IPOs, particularly companies that are similar in their industry. 


\section{Ezgi TUNCAY, Mehmet KARAN, Eren MISKI AYDIN}

Although there have been many studies on the IPO performance of hot and cold markets in developed countries, studies testing cold and hot market hypotheses on emerging countries are still limited. Most of the studies in emerging markets focus on the overall underpricing performance of IPOs in the market without going into details of the market type or firm structure. To our knowledge, there are very few studies covering the post-2008 crisis in Turkey. However, Borsa Istanbul is one of the essential emerging stock markets and is ranked 21st among the world stock markets with 425 million USD total trading value of the equity market in 2018. Its market capitalization is about 140 billion USD and has 416 listed companies. International investors hold approximately $60 \%-70 \%$ of publicly traded shares in Borsa Istanbul (Borsa Istanbul Annual Report 2018). Companies of different sizes are quoted in Borsa Istanbul, but international investors generally pay interest to larger ones. The stock market was particularly thrilled by global developments after the 2008 crisis, as well as the local issues. The performance of the market boosted more than $50 \%$ in 2010 with the persistent interest of foreign investors after the 2008 crisis. But the regional developments reduced the motivation of the investors in the last years. All these events make the exchange one of the volatile markets in the world.

The study aims to investigate the public offering performance of Borsa Istanbul companies, especially during the hot and cold periods of the stock market. Furthermore, as suggested in the previous hypotheses, the factors like the role of industry concentration, company size, and investor optimism on IPO performances will be evaluated and discussed. Within this framework, the performance of 109 publicly traded companies in different industries during the 2010-2017 period is included in the study. The standard short term event study methodology is applied to measure abnormal returns after IPOs. The hypotheses of the study are: (1) The underpricing of IPOs can be seen in Borsa Istanbul, (2) Underpricing prevails in hot market periods, (3) Underpricing phenomenon is more common for small-size companies, (4) Investors' optimism in Borsa Istanbul is one of the driving forces for the underpricing of IPOs, (5) IPOs' observations tend to be clustered around similar industries. 
Focusing on IPOs' performance in Turkey considering hot and cold markets with testing various hypotheses aftermath global crisis is the significant contribution of the study to the IPO literature. We believe that the current research will guide Borsa Istanbul's new companies to have successful public openings and international investors, which pursue market timing along with the financial institutions and policymakers. The rest of the paper is organized as follows. The literature and hypothesis development are given in section two. Data and methodology are explained in the third section. Findings and further discussions are presented in section four, and the paper concludes in section five.

\section{Literature and hypothesis development}

\subsection{Literature}

The initial studies on the underpricing effects of IPOs have started in the early 1970s with the rising popularity of market anomalies in the literature. The evidence of IPO underpricing in the existing literature is attributed to Reilly and Hatfield (1969). They reported the superior performance of new issues by analyzing the returns on the first Friday, fourth Friday, and after one year from issuance. Baron (1982), Rock (1986), Muscarella and Vetsuypens (1989), Welch (1989), Allen and Faulhaber (1989), and Ritter and Welch (2002) support the study of Reilly and Hatfield and find additional evidence on underpricing phenomenon just after the initial public offerings in equity markets.

The first study on the existence of underpricing in the hot markets was published by Ibbotson and Jaffe (1975). They examined the initial public offering companies which went public between 1960 and 1970 . The findings of the study indicate that underpricing is $12.64 \%$ in the hot markets, $11.97 \%$ in cold markets. Besides, it was determined that the issuers offer the stocks at higher prices in the cold markets. Afterward, Ritter (1984) studied 1028 companies that went public in the USA between 1977 and 1982. The period between January 1980 and March 1981 was determined to be hot markets, whereas the remaining period was determined to be cold markets. The average initial return is $48.4 \%$ in hot markets and $16.3 \%$ in cold 


\section{Ezgi TUNCAY, Mehmet KARAN, Eren MISKI AYDIN}

markets. Ritter (1991) explored the initial public offerings between 1975 and 1984 for three years. The low performance varies depending on the year and across industries. The weakest performance was seen in the years where a high-volume of public offerings took place. He found out that poor performance concentrated among relatively young and growing companies.

Helwege \& Liang (2004) examined 6419 IPOs offered to go public in hot and cold markets between 1975 and 2000. They found that the characteristics of the companies that went public are similar to each other. While there is a concentration in related sectors, there are very few differences in the qualities of the firms. The study identifies long-term low performance as a feature of hot markets. Furthermore, more investor optimism exists in hot markets. Ljungqvist, Nanda, and Singh (2006) find evidence of underpricing in the hot markets as well. They showed the existence of an unreasonable enthusiastic investor class as the leading cause of some anomalies such as underpricing, hot markets, and long-term low performance.

Merikas, Gounopoulos, and Nounis's (2009) study on 143 shipping companies that went public in different countries between the years 1984 and 2007 showed that the average return on the first day is $17.69 \%$. However, firms perform poorly at the end of 5 months, and cumulative abnormal return at the end of 36 months is $-35 \%$. Furthermore, they revealed that the shipping companies entering the market during hot periods make lower pricing than those entering the market during the cold periods.

There are also studies on the underpricing of IPOs in the Turkish equity market. Bildik and Yilmaz's (2008) research on 234 companies which were listed on ISE between 1990 and 2000 for 36 months, indicates the effects of factors such as market conditions on stock performance. There is a difference between the hot and cold prices for the first-day average abnormal returns. The average abnormal return on the first day is \%4.46 in the hot markets, whereas it is \%7.13 in the cold markets. This research also found that there is no poor performance for the first public offerings in cold markets in the long-term.

Elmas and Amanianganeh (2013) investigated 227 companies that were offered to the public in BİST for the first time between1995 and 2010. They divided markets into three as hot markets, normal markets, and cold markets. The first-day abnormal 
return is $\% 5.87$ in cold markets, \%5.71 in hot markets, and \%13.17 in normal markets. According to these findings, the first-day abnormal returns obtained in hot and cold markets are very close to each other. However, the first-day abnormal returns received based on the sectors were very different from each other.

Bayram (2015) analyzed 92 IPOs in Istanbul Stock Exchange between1999 and 2009. The first public offering companies were examined separately against many factors for both short (5 days) and long term (36 months). One of the factors discussed in this study was the timing of the public offerings of companies. In the short term, the average residual return of hot markets is $6.6 \%$, and the average residual return of cold markets is $7.8 \%$. In the long term, the average residual return in hot markets is $-47.9 \%$, and the average residual return in cold markets is $-28 \%$.

Çakır, Küçükkocaoğlu, and Kapucu (2017) explored 327 IPOs held in BİST between 1993 and 2015 according to their public offering in hot and cold markets. They found out that the first-day abnormal return is $7.29 \%$ in hot markets and 2.96 $\%$ in cold markets. In addition to this, they demonstrated that there are $10.76 \%$ lower pricing in the short term in hot markets and $10.04 \%$ higher pricing in cold markets. Lastly, Ac1kgoz and Gokkaya (2017) analyzed the Turkish market from 1998 until 2013 and found a significant underpricing in the IPO market. They claimed that factors such as the ratio of the amount of money in insider shares to the total amount, the ratio of the total number of foreign investors to a total number of investors, and the underwriter reputation have a strong effect on underpricing and return volatility.

\subsection{Hypothesis development}

Within the framework of the previous studies mentioned above and the extensive literature on the underpricing anomaly of initial public offerings, there is an underpricing effect not only in the developed countries but also in the developing countries (Katti, Phani 2016). Moreover, various studies provided evidence of the existence of this effect in the Turkish market. Therefore, the first hypothesis of the study is developed as "there is an underpricing anomaly on the Turkish market, depending on the previous literature." 


\section{Ezgi TUNCAY, Mehmet KARAN, Eren MISKI AYDIN}

One of the critical issues related to the underpricing of IPOs is the size of companies. The initial study on this issue is the work of Chalk and Peavy (1987). They claim that low-priced stocks have a significant abnormal return, and this may be attributable to a kind of small firm effect anomaly. Afterward, Ibbotson et al. (1994) used U.S. market data and provided evidence that underpricing is found to occur more frequently on smaller firms than larger firms. M'kombe and Ward (2002) evaluated South African IPOs, an emerging market, and revealed that IPOs with an offer price below 99 cents showed the highest initial returns. Furthermore, they attributed this to the risk premium issue. As the small offerings involve more risk, investors may ask underpricing on IPOs. Heerden and Alagidede's study (2012) demonstrated similar findings at the Johannesburg Stock Exchange (JSE) between 2006 and 2010. They indicate the low priced shares are generally much more significantly underpriced than the high priced shares, and this trend is evident every year except for 2008, where the inverse appears to be true.

However, the Asymmetric Information and Signalling Hypothesis bring a different view to this approach. Rock (1986) hypothesized that some investors were better informed than some others about the quality of the companies that place in the IPO market. Well informed and less informed investors are in competition with each other; the informed ones can not be faced with the problem of adverse selection as others may have. In short, informed investors only invest in high-quality firms that can cover the costs of underpricing. In terms of high-quality companies, they use IPO underpricing as a signal of its value to attract potential investors in the secondary market. Therefore, the degree of underpricing represents the quality of the firm.

Moreover, the probability of being qualified is higher for larger firms in emerging markets. International institutional investors who are the main players in the emerging markets are investing in large firms that are more reputable because of the high risk involved in emerging markets. This finding leads us to investigate whether the firm size effect is valid for big companies in emerging markets or not. Therefore our second hypothesis is that "there is an underpricing effect on AR and CAR of small firms in the short term after the initial public offerings in hot markets." 
The sequential learning, informational externality, and industry concentration hypothesis and the demand for capital hypothesis reveal that sector intensification in public offerings of firms in hot markets is noteworthy (Agathee et al. 2012). Jenkinson and Ljungqvist (2001) demonstrated that there is a strong tendency in this direction, especially in technology companies. Companies often follow companies with similar characteristics in the same sector, benefit from information leaks, and decide to go public after their successful public offering processes. In this process, banks, investment banks, and related players cause information leakage. While there is a correlation between the returns of companies that go public in similar sectors, the underpricing effect is more common.

On the other hand, Helwege and Liang (2004) claimed that clustering of a single industry does not accurately characterize hot markets. Instead, many industries tend to have hot markets at around the same time, and the hot markets attract more of the same kinds of firms. In short, new equity obtained by the companies after the successful initial public offerings attracts the interest of other companies in the same sector with knowledge spill-overs and sequential learning process. Eventually, this process tends towards public offering (Jenkinson, Ljungqvist 2001). Therefore, our third hypothesis is that "initial public offerings initiatives in hot markets tend to be clustered in similar industries."

It has long been believed that the role of investor sentiment is regarded as particularly sensitive in hot markets. The first significant study regarding this point is Lee, Shleifer, and Thaler's work (1991). They claimed that more companies prefer to go public when investor sentiment is high. One of the early studies on this subject was introduced by Otoo (1999). He investigated the relationship between stock prices and consumer confidence indices in the US market in 1999. The study revealed that that stock price movements affect changes in consumer confidence, but the lagged changes in confidence have no significant effect on stock prices. Fisher and Statman (2003) found that increases in consumer confidence about the economy are accompanied by statistically significant increases in the bullishness of individual investors about the stock market. Jansen and Nahuis (2003), Brown and Cliff (2004), found that the current stock prices predict future consumer confidence. 


\section{Ezgi TUNCAY, Mehmet KARAN, Eren MISKI AYDIN}

Derrien (2005), Ljungqvist et al. (2006), Cornelli et al. (2006) and Oehler et al. (2004) found a strong relationship between the underpricing anomaly and investor sentiment and showed that in the initial public offerings, investors can obtain a statistically significant abnormal return during periods of optimism.

Above mentioned studies by considering the Market Timing and Investor Sentiment Hypothesis, link underpricing effect of IPO to overconfidence and the self-attribution. Daniel et al. (1998) described a self-confident investor as someone who overestimates the accuracy of the private information he collects along with the available public information. In the case of the public offering, overconfident investors will be able to make the stock overvalued by paying too much attention to the specific information on an issued stock. In the case of self-attribution bias, investor confidence increases after a positive impulse and decreases less after a negative impulse. During the initial public offerings, this prejudice leads to an overvaluation for the value of the share when high returns are achieved on the first day (Hoffman, Post 2015). In this scope, our fourth and last hypothesis was developed as "there is an underpricing anomaly on AR and CAR of companies just after initial public openings in the markets where consumers are optimistic".

\section{Data and methodology}

The current study had examined the short term daily performance of Borsa Istanbul companies following the public offering dates between 2010 and 2017. This is the period after the global financial crisis that covers important political and economic events in Turkey and in the world. Ending of FED quantitative easing program (2013), Gezi Park protests (2013) ${ }^{1}$, and coup attempt (2016) ${ }^{2}$ are the main global and domestic events that took place during this time. The study covers 109

\footnotetext{
1 The demonstrations and civil unrest throughout the country to protest the urban development plan of Taksim Gezi Park in Istanbul. These events had a negative impact on the financial markets.

${ }^{2}$ On July 15, 2016, a coup attempt organized against the government and state institutions in Turkey. Some members of the army tried to take control of Ankara, Istanbul and many other important places, but this movement failed.
} 
out of 119 IPOs during this period and the event window of the study is the first 15 days. Since 2013, economic and political events have intensified, the number of IPOs are substantially decreased over the years. As seen in Table 1, the number of companies that went public is 86 in the first four years (2010-2013), while only 23 IPOs were realized during the following four years (2014-2017). Moreover, IPOs are concentrated particularly in the industrial and financial sectors. Although the picture looks stable for all years, it is more intense and visible for the first four years. The industries that were categorized as "others" include mostly mining, energy, service, technology sectors. Intense public offerings and high industrial density during the first four years are indicative of the hot period. Depending on the studies of Ibbotson and Jaffe (1975), Ritter (1984) and the Sequential Learning, Informational Externality and Industry Concentration Hypothesis and the Demand for Capital Hypothesis of Jenkinson and Ljungqvist (2001), 2010-2013 period is considered as hot period while 2014-2017 period is called as cold period in this study.

Table 1. Number of IPOs during the 2010-2017 period

\begin{tabular}{|l|c|c|c|c|c|c|c|c|}
\hline Years & $\mathbf{2 0 1 0}$ & $\mathbf{2 0 1 1}$ & $\mathbf{2 0 1 2}$ & $\mathbf{2 0 1 3}$ & $\mathbf{2 0 1 4}$ & $\mathbf{2 0 1 5}$ & $\mathbf{2 0 1 6}$ & $\mathbf{2 0 1 7}$ \\
\hline $\begin{array}{l}\text { Manufacuring } \\
\text { Industry }\end{array}$ & 6 & 7 & 10 & 6 & 8 & 3 & 1 & \\
\hline Finance Industry & 10 & 6 & 4 & 4 & 3 & 2 & & 1 \\
\hline Other Industry & 7 & 9 & 10 & 7 & 2 & 1 & 1 & 1 \\
\hline $\begin{array}{l}\text { Total Number of } \\
\text { IPOs }\end{array}$ & $\mathbf{2 3}$ & $\mathbf{2 2}$ & $\mathbf{2 4}$ & $\mathbf{1 7}$ & $\mathbf{1 3}$ & $\mathbf{6}$ & $\mathbf{1}$ & $\mathbf{3}$ \\
\hline
\end{tabular}

Since the size effect of IPOs is investigated in hot and cold periods, following Chalk and Peavy (1987) and Ibbotson et al. (1994) whom found underpricing as more common for big companies, the companies are grouped as big and small according to company size. The average firm capitalization value of the 109 companies examined in the current study is 180,763,911 USD. Out of these 


\section{Ezgi TUNCAY, Mehmet KARAN, Eren MISKI AYDIN}

companies 23 of them are selected as big and 86 of them are considered as small ones.

Consumer confidence is one of the leading economic indicators of economies. The consumer confidence index is used to measure optimism levels of investors for the study. It measures how confident consumers are about the overall state of the economy. The Consumer Confidence Index is a survey that measures how optimistic or pessimistic consumers are regarding their expected financial situation, led by the State Statistical Institute in Turkey. Moreover, the index predicts household expenditures and economic activity of the countries (Fisher, Statman 2003). Their confidence impacts their economic decisions - like their spending activity. As a result, consumer confidence is a key indicator of the overall shape of the economy (Chen 2011). Consumer confidence generally moves in line with economic variables such as interest rates, inflation, and unemployment, but sometimes it diverges from them. The normal level of the index is 100 points. If the Index is above 100, consumers are accepted as more confident, and if it is below 100, then they are accepted as less confident.

Within our study, all years were found below 100, which is generally considered as low for the confidence index. However, after the seasonal adjustments made between 2010 and 2017, the average of the consumer confidence index is found as 72.2 (Table 2). Taking into consideration the global economic crisis and the special conditions of the country after 2010, the years were divided into two groups according to the mean value. The years above, the mean value is named as optimistic, and others are called as pessimistic. Therefore 2010, 2011 2012, 2013, and 2015 are optimistic years. This distinction fits mostly with the period of cold and hot markets. The only exception is the year 2015, which is considered a cold one, enters the optimistic group. This picture is consistent with the claims of Ljungqvist, Nanda, and Singh (2005) and Lee, Shleifer, and Thaler (1991). They reveal that as the optimism of sentiment investors increases, more companies have an incentive to go public. 
Table 2. The confidence index, after seasonal adjustments for the 2010-2017 period

\begin{tabular}{|c|c|c|}
\hline Years & Confidence Index & State of Index \\
\hline 2010 & 77.7659 & Optimistic \\
\hline 2011 & 78.8204 & Optimistic \\
\hline 2012 & 73.9561 & Optimistic \\
\hline 2013 & 75.3538 & Optimistic \\
\hline 2014 & 68.1513 & Pessimistic \\
\hline 2015 & 74.0110 & Optimistic \\
\hline 2016 & 63.8691 & Pessimistic \\
\hline 2017 & 65.6352 & Pessimistic \\
\hline Average & 72.1954 & \\
\hline
\end{tabular}

Table 3. Descriptive statistics of the variables

\begin{tabular}{|l|r|r|r|r|r|r|r|r|}
\hline Variables & \multicolumn{1}{c|}{$\mathbf{N}$} & Range & Min. & \multicolumn{1}{c|}{ Max. } & Mean & $\begin{array}{c}\text { SE of } \\
\text { Mean }\end{array}$ & Std. Dev. & Variance \\
\hline HotCold & 109 & 1.00 & .00 & 1.00 & .789 & .0392 & \multicolumn{1}{c|}{0.410} & \multicolumn{1}{c|}{.168} \\
\hline LnSize & 109 & 6.59 & 15.32 & 21.91 & 17.827 & .1371 & 1.432 & \multicolumn{1}{c|}{2.050} \\
\hline $\begin{array}{l}\text { Manufactur } \\
\text { ing }\end{array}$ & 109 & 1.00 & .00 & 1.00 & .367 & .0469 & 0.484 & .234 \\
\hline Finance & 109 & 1.00 & .00 & 1.00 & .266 & .0425 & 0.444 & .197 \\
\hline Others & 109 & 1.00 & .00 & 1.00 & .367 & .0462 & 0.484 & .234 \\
\hline Confidence & 109 & 14.95 & 63.87 & 78.82 & 74.949 & .3602 & 3.761 & 14.145 \\
\hline Inflation & 109 & 5.76 & 6.16 & 11.92 & 7.835 & .1664 & 1.738 & 3.019 \\
\hline Car1 & 109 & .33 & -.11 & .23 & .016 & .0062 & 0.065 & .004 \\
\hline Car5 & 109 & .90 & -.17 & .74 & .048 & .0153 & 0.160 & .025 \\
\hline Car10 & 109 & 1.24 & -.32 & .92 & .035 & .0173 & 0.181 & .033 \\
\hline Car15 & 109 & 1.26 & -.45 & .80 & .042 & .0188 & 0.196 & .039 \\
\hline
\end{tabular}

The summary statistics of the variables are given in Table 3. "Hot-Cold dummy" is 1 ; if the period of IPO is hot, otherwise 0 . Size is one of the independent variables of the model. The market value of equity of a company is used, and it is converted to the natural $\log$ to normalize its values. The other variables are "Manufacturing," 
"Finance," and "Others" dummies. If the companies belong to these industries, their value is 1 , otherwise 0 . "Confidence" variable is the average yearly consumer confidence index. Lastly, the inflation variable shows the yearly inflation rates. Furthermore, the values of the 1 st, 5 th, $10^{\text {th }}$, and $15^{\text {th }}$ days are given in the table.

Table 4. Descriptive statistics of IPOs in hot and cold markets

\begin{tabular}{|c|c|c|c|c|c|c|}
\hline Variables & $\begin{array}{l}\text { HotCol } \\
\text { d }\end{array}$ & $\mathrm{N}$ & Mean & $\begin{array}{l}\text { Sig. of Mean } \\
\text { Difference }\end{array}$ & $\begin{array}{c}\text { Std. } \\
\text { Deviation }\end{array}$ & $\begin{array}{c}\text { Std. Error } \\
\text { Mean }\end{array}$ \\
\hline \multirow[b]{2}{*}{ LnSize } & 1.00 & 86 & 17.952 & \multirow{2}{*}{$\begin{array}{c}1.917 \\
(0.063)^{*}\end{array}$} & 1.453 & 0.157 \\
\hline & .00 & 23 & 17.362 & & 1.273 & 0.266 \\
\hline \multirow{2}{*}{ Manufactur } & 1.00 & 86 & 0.326 & \multirow{2}{*}{$\begin{array}{l}-1.6620 \\
(0.084)^{*}\end{array}$} & 0.471 & 0.051 \\
\hline & .00 & 23 & 0.522 & & 0.511 & 0.107 \\
\hline \multirow{2}{*}{ Finance } & 1.00 & 86 & 0.267 & \multirow{2}{*}{$\begin{array}{l}0.0620 \\
(0.951)\end{array}$} & 0.445 & 0.048 \\
\hline & .00 & 23 & 0.261 & & 0.449 & 0.094 \\
\hline \multirow[b]{2}{*}{ Confidence } & 1.00 & 86 & 76.496 & \multirow{2}{*}{$\begin{array}{c}10.580 \\
(0.000)^{* * *}\end{array}$} & 1.979 & 0.213 \\
\hline & .00 & 23 & 69.166 & & 3.160 & 0.659 \\
\hline \multirow{2}{*}{ Car1 } & 1.00 & 86 & 0.018 & \multirow{2}{*}{$\begin{array}{c}0.961 \\
(0.341))\end{array}$} & 0.069 & 0.007 \\
\hline & .00 & 23 & 0.006 & & 0.048 & 0.010 \\
\hline \multirow[b]{2}{*}{ Car5 } & 1.00 & 86 & 0.053 & \multirow{2}{*}{$\begin{array}{c}0.617 \\
(0.541))\end{array}$} & 0.168 & 0.018 \\
\hline & .00 & 23 & 0.033 & & 0.124 & 0.026 \\
\hline \multirow[b]{2}{*}{ Car10 } & 1.00 & 86 & 0.040 & \multirow{2}{*}{$\begin{array}{c}0.773 \\
(0.466))\end{array}$} & 0.197 & 0.021 \\
\hline & .00 & 23 & 0.018 & & 0.105 & 0.022 \\
\hline \multirow{2}{*}{ Car15 } & 1.00 & 86 & 0.046 & \multirow{2}{*}{$\begin{array}{c}0.563 \\
(0.575)\end{array}$} & 0.212 & 0.023 \\
\hline & .00 & 23 & 0.026 & & 0.125 & 0.026 \\
\hline
\end{tabular}

$*, * *$ and $* * *$ indicate significance level of $0.10,0.05$ and 0.01 respectively.

Equal Variance is not assumed for the $t$ test of mean differences. 


\section{UNDERPRICING OF INITIAL PUBLIC OFFERINGS IN HOT AND COLD MARKETS}

Before the case analysis, the mean values of CARs and other variables were compared with the hot and cold periods. In this way, the preliminary reliability of the study was evaluated. As shown in Table 4, CAR averages are positive in both hot and cold markets. In other words, it can be considered as an evidence on the existence of underprice anomaly both in cold and hot markets. Moreover the mean differences of them are not statistically significant. However, the average of hot markets is higher. The average IPO size and confidence level in hot markets are higher and significant. Significance level of the confidence index is remarkable. Contrary to our expectations, the manufacturing sector provides higher premiums during cold periods with $10 \%$ significance level. There is no significant difference in the means of the financial sector companies.

We adopt the standard event study methodology to measure the impact of an event on stock returns by selecting an event window as 15 days, following the day of IPOs. In this way, the abnormal returns and cumulative abnormal returns are calculated; the hypotheses are tested and discussed. More specifically, by using event study methodology, we measure whether the public offerings could have an effect on prices of related stocks and the direction and magnitude of any perceived effects might have on those stock prices.

To estimate ex-ante expected returns, the market-adjusted abnormal returns model is used. This model assumes that the ex-ante expected returns are constant across securities but not enforcedly stable over time for given security since all securities in the sample are assumed to be equal in terms of the size and the risk. Market adjusted abnormal returns are simply the difference between actual returns and the market return as given below;

$E(R i, t)=R m, t$

As stated before, the expected return is the market return $(\mathrm{Rm}, \mathrm{t})$ at the same period of time, assuming that all stocks, on average, generate the same rate of return (Ritter 1991). The main simplicity of this model is that it does not need an estimation period. An abnormal return for an individual stock is the difference between the actual return on time ( $\mathrm{t}$ ) in the event window and the expected return of an individual stock. The mathematical expression of the abnormal return and the 
average abnormal return for all sample stocks on time (t) can be calculated as follows;

$A R i, t=R_{i, t^{-}} E\left(R_{i, t}\right)$

$\overline{A R^{\prime \prime}}=\frac{1}{N} \sum_{i=1}^{N} A R_{i, t}$

To calculate cumulative abnormal return (CAR) for 1-15 days (T1-T15) event window for an individual stock, the standard formula is used;

$C A R_{i(T 1, T 15)}=\sum_{t=T 1}^{T 15} A R_{i, t}$

Since abnormal returns are expected to be zero and no underpricing anomaly in the efficient markets, we test if the abnormal and cumulative abnormal returns in our event window significantly from zero by employing $t$ statistics. The mathematical expression of the t-tests for AR and CAR;

$t_{A R}=\frac{A R_{i, t}}{S_{e_{i, t}}} \quad t_{C A R}=\overline{C A R_{i, t}} /\left(\sigma\left(C A R_{i, t}\right) / \sqrt{n}\right.$

\section{Findings}

Firstly, daily AR and CAR and $t$ statistics of all companies included in the analysis were calculated within the scope of our event window during the 2010 and 2017 period. The result presented in Table 5 reveals an underpricing effect in the Turkish market. The first day average AR and CAR values of the stocks are significantly different from zero and they are $1.66 \%$ and $1.59 \%$, respectively. The finding is consistent with previous literature (Çakır et al. 2017). Among the IPOs 
included in the analysis, 50 of them has positive returns. In other words underpricing at the end of 15 days, whereas 59 of them have negative returns, which means overpricing. In the first four days, a low price effect is observed for AR values, but the effect is significant for all CAR values. These findings clearly indicate that the underpricing phenomenon is common in IPOs of Borsa Istanbul companies aftermath of the global crisis.

Table 5. AR and CAR values of the all IPOs in the sample

\begin{tabular}{|l|l|l|}
\hline DAY & \multicolumn{1}{|c|}{ AR CAR } \\
\hline $\mathrm{t}+1$ & $0.0159 * * *$ & $0.0159 * * *$ \\
\hline $\mathrm{t}+2$ & $0.0116^{* *}$ & $0.0275^{* * *}$ \\
\hline $\mathrm{t}+3$ & $0.0063^{*}$ & $0.0341^{* * *}$ \\
\hline $\mathrm{t}+4$ & $0.0100^{* * *}$ & $0.0441 * * *$ \\
\hline $\mathrm{t}+5$ & 0.0046 & $0.0485^{* * *}$ \\
\hline $\mathrm{t}+6$ & $-0.0067 * *$ & $0.0415^{* * *}$ \\
\hline $\mathrm{t}+7$ & -0.0035 & $0.0379 * * *$ \\
\hline $\mathrm{t}+8$ & 0.0016 & $0.0396 * * *$ \\
\hline $\mathrm{t}+9$ & -0.0027 & $0.0370 * *$ \\
\hline $\mathrm{t}+10$ & -0.0018 & $0.0353 * *$ \\
\hline $\mathrm{t}+11$ & -0.0021 & $0.0331 *$ \\
\hline $\mathrm{t}+12$ & $0.0061 * *$ & $0.0394 * *$ \\
\hline $\mathrm{t}+13$ & 0.0021 & $0.0415 * *$ \\
\hline $\mathrm{t}+14$ & 0.0006 & $0.0420 * *$ \\
\hline $\mathrm{t}+15$ & 0.0037 & $0.0459 * *$ \\
\hline
\end{tabular}

$*, * *$ and $* * *$ indicate significance level of $0.10,0.05$ and 0.01 respectively.

\subsection{Hot and cold market}

In the second stage of the research, AR and CAR values of the sample were calculated separately for hot and cold markets which was defined before and searched the existence of underpricing for the IPOs of Borsa Istanbul as claimed in previous studies. As presented in Table 6, the existence of underpricing is significant in the hot market. The AR values in two days are significant respectively at $1 \%$ and 5\% level. Day 6, 11 and 12 are positive and significantly different from zero. 
However, underpricing is more common for the CAR values, the CAR of all days are significant. On the other hand, AR and CAR values are positive and there is very weak underpricing in the cold market. However, this effect significantly comes up only in a few days. The result supports previous studies (Katti, Phani 2016).

\section{Table 6. AR and CAR values of the IPOs in hot and cold markets}

\begin{tabular}{|c|c|c|c|c|}
\hline Days & $\begin{array}{c}\text { AR } \\
\text { Hot Market }\end{array}$ & $\begin{array}{c}\text { CAR } \\
\text { Hot Market }\end{array}$ & $\begin{array}{c}\text { AR } \\
\text { Cold Market }\end{array}$ & $\begin{array}{c}\text { CAR } \\
\text { Cold Market }\end{array}$ \\
\hline 1 & $0.0184 * * *$ & $0.0184 * * *$ & 0.0064 & 0.0064 \\
\hline 2 & $0.0138 * *$ & $0.0322 * * *$ & 0.0036 & 0.0100 \\
\hline 3 & 0.0069 & $0.0391 * * *$ & 0.0042 & 0.0142 \\
\hline 4 & $0.0063^{*}$ & $0.0454 * * *$ & $0.0239 * *$ & $0.0381 * *$ \\
\hline 5 & $0.0071 *$ & $0.0526 * * *$ & -0.0051 & 0.0330 \\
\hline 6 & $-0.0089 * *$ & $0.0437 * * *$ & 0.0016 & 0.0346 \\
\hline 7 & -0.0027 & $0.0410 * *$ & -0.0063 & 0.0283 \\
\hline 8 & 0.0006 & $0.0416^{* *}$ & $0.0057 * * *$ & 0.0340 \\
\hline 9 & -0.0008 & $0.0408 * *$ & $-0.0096 * *$ & 0.0244 \\
\hline 10 & -0.0005 & $0.0402 * *$ & -0.0065 & 0.0178 \\
\hline 11 & $-0.0083^{*}$ & $0.0319 *$ & 0.0012 & 0.0191 \\
\hline 12 & $0.0081 * *$ & $0.0400 * *$ & -0.0002 & 0.0189 \\
\hline 13 & 0.0022 & $0.0422 * *$ & 0.0011 & 0.0200 \\
\hline 14 & 0.0002 & $0.0424 * *$ & 0.0018 & 0.0218 \\
\hline 15 & 0.0035 & $0.0459 * *$ & 0.0046 & 0.0264 \\
\hline
\end{tabular}

$*, * *$ and $* * *$ indicate significance level of $0.10,0.05$ and 0.01 respectively.

\subsection{Size of the companies}

The studies of Chalk and Peavy (1987), Ibbotson et al. (1994), and considering the Asymmetric Information and Signalling Hypothesis, we investigated the impact of size on the underpricing effect at Borsa Istanbul public offerings. The IPO performance of large and small companies in hot markets is presented in Table 7. Findings indicate that there is no significant underpricing effect for the AR and CAR values of large firms in general. In terms of AR values, there is slight overpricing at a low significance level on the second day, whereas a significant overpricing occurs on the third day. However, in terms of the small companies, while the overpricing 
effect is observed in the first six daily ARs, a widespread low price effect is observed amongst CAR values. This result is consistent with the findings of Chalk and Peavy (1987), and Ibbotson et al. (1994) underline the existence of widespread underpricing for small firms during the hot years of the post-crisis period in the Turkish market. However, when the daily returns are examined, it is seen that the values are very close to zero for all companies, and there are positive returns for the big firms even if they are not significant. Therefore, it is not easy to claim that there is a strong underpricing effect for small firms.

On the other hand, in terms of the cold market, the results are quite different than the hot market case. According to the findings, the underpricing phenomenon for small firms is relatively weakened in the cold markets. Only AR performance on $4^{\text {th }}$ and $8^{\text {th }}$ days are significant, and CAR values on the $4^{\text {th }}$ day are $5 \%$ significant; the following two CARs in $5^{\text {th }}$ and $6^{\text {th }}$ days are at a $10 \%$ significance level. Similarly, the AR for the big firms in the cold markets have no IPO premium, even a widespread overpricing effect is observed.

Table 7. AR and CAR values of the IPOs in hot and cold markets grouped by size

\begin{tabular}{|c|c|c|c|c|c|c|c|c|}
\hline \multirow{2}{*}{ Days } & \multicolumn{2}{|c|}{$\begin{array}{c}\text { AR } \\
\text { Hot Markets }\end{array}$} & \multicolumn{2}{|c|}{$\begin{array}{c}\text { AR } \\
\text { Cold Markets }\end{array}$} & \multicolumn{2}{|c|}{$\begin{array}{c}\text { CAR } \\
\text { Hot Markets }\end{array}$} & \multicolumn{2}{|c|}{$\begin{array}{c}\text { CAR } \\
\text { Cold Markets }\end{array}$} \\
\hline & $\begin{array}{l}\text { Big } \\
\text { Firms }\end{array}$ & $\begin{array}{l}\text { Small } \\
\text { Firms }\end{array}$ & Big Firms & $\begin{array}{l}\text { Small } \\
\text { Firms }\end{array}$ & $\begin{array}{l}\text { Big } \\
\text { Firms }\end{array}$ & $\begin{array}{l}\text { Small } \\
\text { Firms }\end{array}$ & $\begin{array}{l}\text { Big } \\
\text { Firms }\end{array}$ & $\begin{array}{l}\text { Small } \\
\text { Firms }\end{array}$ \\
\hline 1 & 0.0100 & $\begin{array}{l}0.0210 \\
* *\end{array}$ & -0.0066 & 0.0084 & 0.0100 & $\begin{array}{l}0.0210 \\
* *\end{array}$ & -0.0066 & 0.0084 \\
\hline 2 & $0.0154 *$ & $0.0133 *$ & 0.0023 & 0.0038 & 0.0255 & $\begin{array}{l}0.0343 \\
* *\end{array}$ & -0.0043 & 0.0121 \\
\hline 3 & $\begin{array}{l}- \\
0.0146 * * \\
*\end{array}$ & $\begin{array}{l}0.0134 * \\
*\end{array}$ & $\begin{array}{l}-0.0114 \\
* * *\end{array}$ & 0.0066 & 0.0109 & $\begin{array}{l}0.0477 \\
* * *\end{array}$ & $\begin{array}{l}- \\
0.0157 * \\
*\end{array}$ & 0.0187 \\
\hline 4 & 0.0018 & $0.0077 *$ & -0.0007 & $0.0276 * *$ & 0.0127 & $\begin{array}{l}0.0553 \\
* * *\end{array}$ & $\begin{array}{l}- \\
0.0164 * \\
*\end{array}$ & $\begin{array}{l}0.0463 * \\
*\end{array}$ \\
\hline 5 & 0,0062 & $0.0074 *$ & -0.0081 & -0.0047 & 0.0189 & $\begin{array}{l}0.0628 \\
* * *\end{array}$ & - $0.0246 *$ & $0.0417 *$ \\
\hline 6 & -0.0058 & $\begin{array}{l}- \\
0.0098 * \\
*\end{array}$ & -0.0045 & 0.0025 & 0.0130 & $\begin{array}{l}0.0530 \\
* * *\end{array}$ & $\begin{array}{l}-0.0291 \\
* * *\end{array}$ & $0.0442 *$ \\
\hline 7 & -0.0030 & -0.0026 & -0.0033 & -0.0068 & 0.0101 & $\begin{array}{l}0.0504 \\
* *\end{array}$ & $\begin{array}{l}-0.0324 \\
* *\end{array}$ & 0.0374 \\
\hline
\end{tabular}




\section{Ezgi TUNCAY, Mehmet KARAN, Eren MISKI AYDIN}

Table 7. Cont....

\begin{tabular}{|c|c|c|c|c|c|c|c|c|}
\hline \multirow{2}{*}{ Days } & \multicolumn{2}{|c|}{$\begin{array}{c}\text { AR } \\
\text { Hot Markets }\end{array}$} & \multicolumn{2}{|c|}{$\begin{array}{c}\text { AR } \\
\text { Cold Markets }\end{array}$} & \multicolumn{2}{|c|}{$\begin{array}{c}\text { CAR } \\
\text { Hot Markets }\end{array}$} & \multicolumn{2}{|c|}{$\begin{array}{c}\text { CAR } \\
\text { Cold Markets }\end{array}$} \\
\hline & $\begin{array}{l}\text { Big } \\
\text { Firms }\end{array}$ & $\begin{array}{l}\text { Small } \\
\text { Firms }\end{array}$ & Big Firms & $\begin{array}{l}\text { Small } \\
\text { Firms }\end{array}$ & $\begin{array}{l}\text { Big } \\
\text { Firms }\end{array}$ & $\begin{array}{l}\text { Small } \\
\text { Firms }\end{array}$ & $\begin{array}{l}\text { Big } \\
\text { Firms }\end{array}$ & $\begin{array}{l}\text { Small } \\
\text { Firms }\end{array}$ \\
\hline 8 & 0.0043 & -0.0006 & -0.0036 & $\begin{array}{l}0.0071 \\
* * *\end{array}$ & 0.0143 & $\begin{array}{l}0.0498 \\
* *\end{array}$ & $\begin{array}{l}-0.0360 \\
* *\end{array}$ & $\begin{array}{l}0.0445 \\
*\end{array}$ \\
\hline 9 & 0.0006 & -0.0012 & $\begin{array}{l}-0.0072 \\
*\end{array}$ & $\begin{array}{l}-0.0100 \\
*\end{array}$ & 0.0149 & $\begin{array}{l}0.0486 \\
* *\end{array}$ & $\begin{array}{l}-0.0432 \\
* * *\end{array}$ & 0.0345 \\
\hline 10 & 0.0023 & -0.0014 & -0.0001 & -0.0075 & 0.0173 & $\begin{array}{l}0.0472 \\
* *\end{array}$ & $\begin{array}{l}-0.0434 \\
* *\end{array}$ & 0.0270 \\
\hline 11 & -0.0225 & -0.0040 & -0.0449 & 0.0082 & -0.0052 & $\begin{array}{l}0.0432 \\
* *\end{array}$ & $\begin{array}{l}-0.0883 \\
* *\end{array}$ & $\begin{array}{l}0.0352 \\
*\end{array}$ \\
\hline 12 & $\begin{array}{l}0.0079 \\
* *\end{array}$ & 0.0081 & 0.0192 & -0.0031 & 0.0027 & $\begin{array}{l}0.0513 \\
* *\end{array}$ & $\begin{array}{l}-0.0691 \\
* * *\end{array}$ & 0.0321 \\
\hline 13 & 0.0009 & 0.0025 & $0.0067 *$ & 0.0003 & 0.0036 & 0.0539 & $\begin{array}{l}-0.0624 \\
* *\end{array}$ & 0.0324 \\
\hline 14 & -0.0024 & 0.0010 & -0.0006 & 0.0022 & 0.0012 & 0.0549 & $\begin{array}{l}-0.0630 \\
* *\end{array}$ & $\begin{array}{l}0.0345 \\
* *\end{array}$ \\
\hline 15 & 0.0008 & 0.0043 & -0.0070 & 0.0063 & 0.0020 & 0.0592 & $\begin{array}{l}-0.0700 \\
* * *\end{array}$ & 0.0408 \\
\hline
\end{tabular}

$*, * *$ and $* * *$ indicate significance level of $0.10,0.05$ and 0.01 respectively.

\subsection{Industry concentration}

Building on the premises of the hypotheses of sequential learning, informational externality, industry concentration, and demand for capital, underpricing is widely expected in particular industries during the hot periods. However, our findings are not actively supporting the hypotheses. The returns of IPO concentrated industries do not behave similarly in hot markets (Table 8). Whereas CAR values of the manufacturing sector especially indicate underpricing during the first week after the public offering. It is observed that there are weak significant outcomes in the financial sector. There is also a widespread low price effect in the "other" industry group. These results are not in line with the claims put forward in the hypotheses. Therefore, we reject the third hypothesis of the study that claims initial public offerings initiatives in hot markets tend to be clustered in similar industries. 
Table 8. AR and CAR values of IPOs in the hot markets grouped by industries

\begin{tabular}{|c|l|l|l|l|l|l|}
\hline \multirow{2}{*}{ Days } & \multicolumn{3}{|c|}{ AR (Hot Markets) } & \multicolumn{3}{c|}{ CAR (Hot Markets) } \\
\cline { 2 - 7 } & Manf. & Finance & Others & Manf. & Finance & Others \\
\hline 1 & $0.0218^{*}$ & 0.0142 & 0.0185 & $0.0218^{* *}$ & 0.0142 & $0.0185^{*}$ \\
\hline 2 & 0.0103 & 0.0128 & $0.0175^{*}$ & $0.0321^{*}$ & 0.0270 & $0.0361^{* *}$ \\
\hline 3 & 0.0150 & 0.0004 & 0.0045 & $0.0471^{*}$ & 0.0274 & $0.0406^{* *}$ \\
\hline 4 & $0.0121^{* *}$ & 0.0092 & -0.0009 & $0.0592^{* *}$ & $0.0366^{*}$ & 0.0397 \\
\hline 5 & 0.0091 & 0.0069 & 0.0056 & $0.0683^{* *}$ & $0.0435^{*}$ & $0.0453^{* *}$ \\
\hline 6 & $-0.0087^{*}$ & -0.0039 & $-0.0126^{* *}$ & $0.0596^{*}$ & $0.0396^{*}$ & $0.0327^{*}$ \\
\hline 7 & -0.0080 & -0.0009 & 0.0006 & 0.0516 & $0.0388^{*}$ & $0.0333^{*}$ \\
\hline 8 & 0.0034 & 0.0005 & -0.0019 & $0.0550^{*}$ & $0.0393 *$ & 0.0314 \\
\hline 9 & -0.0054 & 0.0012 & 0.0018 & 0.0495 & $0.0405^{*}$ & 0.0333 \\
\hline 10 & $-0.0092^{*}$ & -0.0038 & 0.0094 & 0.0403 & 0.0367 & 0.0427 \\
\hline 11 & -0.0035 & -0.0052 & -0.0011 & 0.0368 & 0.0315 & 0.0416 \\
\hline 12 & $0.0076^{*}$ & 0.0058 & 0.0095 & 0.0443 & 0.0373 & $0.0512^{*}$ \\
\hline 13 & -0.0019 & -0.0041 & $0.0107 * *$ & 0.0425 & 0.0332 & $0.0618^{* *}$ \\
\hline 14 & 0.0079 & -0.0031 & -0.0040 & 0.0504 & 0.0301 & $0.0579 *$ \\
\hline 15 & $0.0104 *$ & $-0.0054^{*}$ & 0.0039 & 0.0607 & 0.0247 & $0.0617^{* *}$ \\
\hline$* * 2$
\end{tabular}

$*, * *$ and $* * *$ indicate significance level of $0.10,0.05$ and 0.01 respectively.

In the case of cold markets, there is no underpricing effect at a remarkable level in any industry group (Table 9). Although ARs reflect underpricing effects in the groups of manufacturing and finance, no underpricing has been observed in CARs in none of the industry groups. These findings are in line with previous studies.

Table 9. AR and CAR values of IPOs in the cold markets grouped by industries

\begin{tabular}{|c|l|l|l|l|l|l|}
\hline \multirow{2}{*}{ Days } & \multicolumn{3}{|c|}{ AR (Cold Markets) } & \multicolumn{3}{c|}{ CAR (Cold Markets) } \\
\cline { 2 - 7 } & Manf. & Finance & Others & Manf. & Finance & Others \\
\hline 1 & 0.0099 & 0.0044 & 0.0007 & 0.0099 & 0.0044 & 0.0007 \\
\hline 2 & 0.0073 & 0.0069 & -0.0093 & 0.0171 & 0.0113 & -0.0087 \\
\hline 3 & -0.0003 & 0.0075 & 0.0112 & 0.0168 & 0.0188 & 0.0026 \\
\hline 4 & 0.0104 & 0.0277 & 0.0519 & 0.0272 & 0.0464 & 0.0544 \\
\hline 5 & $-0.0154 *$ & -0.0053 & 0.0198 & 0.0118 & 0.0412 & 0.0742 \\
\hline
\end{tabular}


Ezgi TUNCAY, Mehmet KARAN, Eren MISKI AYDIN

Table 9. Cont. ...

\begin{tabular}{|c|l|l|l|l|l|l|}
\hline \multirow{2}{*}{ Days } & \multicolumn{3}{|c|}{ AR (Cold Markets) } & \multicolumn{3}{c|}{ CAR (Cold Markets) } \\
\cline { 2 - 7 } & Manf. & Finance & Others & Manf. & Finance & Others \\
\hline 6 & -0.0043 & 0.0008 & 0.0168 & 0.0075 & 0.0419 & 0.0910 \\
\hline 7 & -0.0017 & -0.0153 & -0.0065 & 0.0058 & 0.0266 & 0.0845 \\
\hline 8 & $0.0095^{* * *}$ & 0.0018 & 0.0013 & 0.0153 & 0.0284 & 0.0858 \\
\hline 9 & 0.0023 & $-0.0235^{* *}$ & -0.0217 & 0.0176 & 0.0049 & 0.0641 \\
\hline 10 & -0.0003 & 0.0009 & $-0.0305^{*}$ & 0.0173 & 0.0058 & 0.0336 \\
\hline 11 & 0.0013 & 0.0001 & 0.0026 & 0.0186 & 0.0059 & 0.0362 \\
\hline 12 & 0.0033 & -0.0037 & -0.0044 & 0.0219 & 0.0022 & 0.0318 \\
\hline 13 & 0.0030 & -0.0025 & 0.0009 & 0.0249 & -0.0003 & 0.0326 \\
\hline 14 & 0.0012 & $-0.0095^{* *}$ & $0.0168^{*}$ & 0.0261 & -0.0098 & 0.0494 \\
\hline 15 & -0.0026 & -0.0021 & 0.0298 & 0.0235 & -0.0119 & 0.0793 \\
\hline
\end{tabular}

$*, * *$ and $* * *$ indicate significance level of $0.10,0.05$ and 0.01 respectively.

\subsection{Confidence index}

According to the Market Timing and Investor Sentiment Hypothesis, there is a positive relationship between sentiment, investor optimism, and IPO activity. Investors can time their IPO's to benefit from these positive conditions of the market. The results given in Table 10 are entirely consistent with the hypothesis. Indeed, this is not a surprising finding as consumer confidence periods widely covered the hot period of our research. Thus, the results are consistent with the outcomes of the hot periods. In periods of high confidence index, both AR and CAR indicate the presence of an underpricing effect (Table 10).

Although the year 2015 is not in the hot period, it is covered by the confidence index. Therefore, the IPO performance of this year is given explicitly in Figure 1. The results indicate that there has been 0,5 and 0,3 percent AR underpricing at the $5 \%$ significant level, respectively, in the $4^{\text {th }}$ and $13^{\text {th }}$ days. The widespread underpricing for CAR values is seen between $4^{\text {th }}$ and $15^{\text {th }}$ days with $\% 5$ and $\% 10$ significance levels. Even though the significance levels of returns are so high, it will not be a mistake to express the underpricing effect on the IPO market in 2015, according to this picture. The findings support the acceptance of the fourth hypothesis. 
Table 10. AR and CAR values of the IPOs in high and low consumer confidence periods

\begin{tabular}{|c|c|c|c|c|}
\hline Days & $\begin{array}{c}\text { AR } \\
\text { High Consumer } \\
\text { Confidence }\end{array}$ & $\begin{array}{c}\text { CAR } \\
\text { High Consumer } \\
\text { Confidence }\end{array}$ & $\begin{array}{c}\text { AR } \\
\text { Low Consumer } \\
\text { Confidence }\end{array}$ & $\begin{array}{c}\text { CAR } \\
\text { Low } \\
\text { Consumer } \\
\text { Confidence } \\
\end{array}$ \\
\hline 1 & $0.018371 * * *$ & $0.0183 * * *$ & 0.0026 & 0.0026 \\
\hline 2 & $0.014578 * *$ & $0.0329 * * *$ & -0.0044 & -0.0018 \\
\hline 3 & $0.007488^{*}$ & $0.0404 * * *$ & 0.0001 & -0.0017 \\
\hline 4 & $0.009668 * *$ & $0.0501 * * *$ & 0.0119 & 0.0102 \\
\hline 5 & 0.005437 & $0.0555^{* * *}$ & -0.0002 & 0.0100 \\
\hline 6 & $-0.00882 * * *$ & $0.0467 * * *$ & 0.0050 & 0.0151 \\
\hline 7 & -0.00245 & $0.0442 * * *$ & $-0.0090^{*}$ & 0.0061 \\
\hline 8 & 0.000854 & $0.0451 * * *$ & $0.0059 * * *$ & 0.0120 \\
\hline 9 & -0.00153 & $0.0435^{* *}$ & $-0.0088^{* * *}$ & 0.0033 \\
\hline 10 & 0.0000 & $0.0435 * *$ & $-0.0113^{* *}$ & -0.0081 \\
\hline 11 & -0.00763 & $0.0359 * *$ & 0.0010 & -0.0070 \\
\hline 12 & $0.008032 * *$ & $0.0439 * *$ & -0.0029 & -0.0099 \\
\hline 13 & 0.00216 & $0.0461 * *$ & 0.0008 & -0.0091 \\
\hline 14 & 0.000285 & $0.04640 * *$ & 0.0021 & -0.0071 \\
\hline 15 & 0.002742 & $0.04914 * *$ & 0.0089 & 0.0019 \\
\hline
\end{tabular}

*,** and *** indicate significance level of $0.10,0.05$ and 0.01 respectively. 


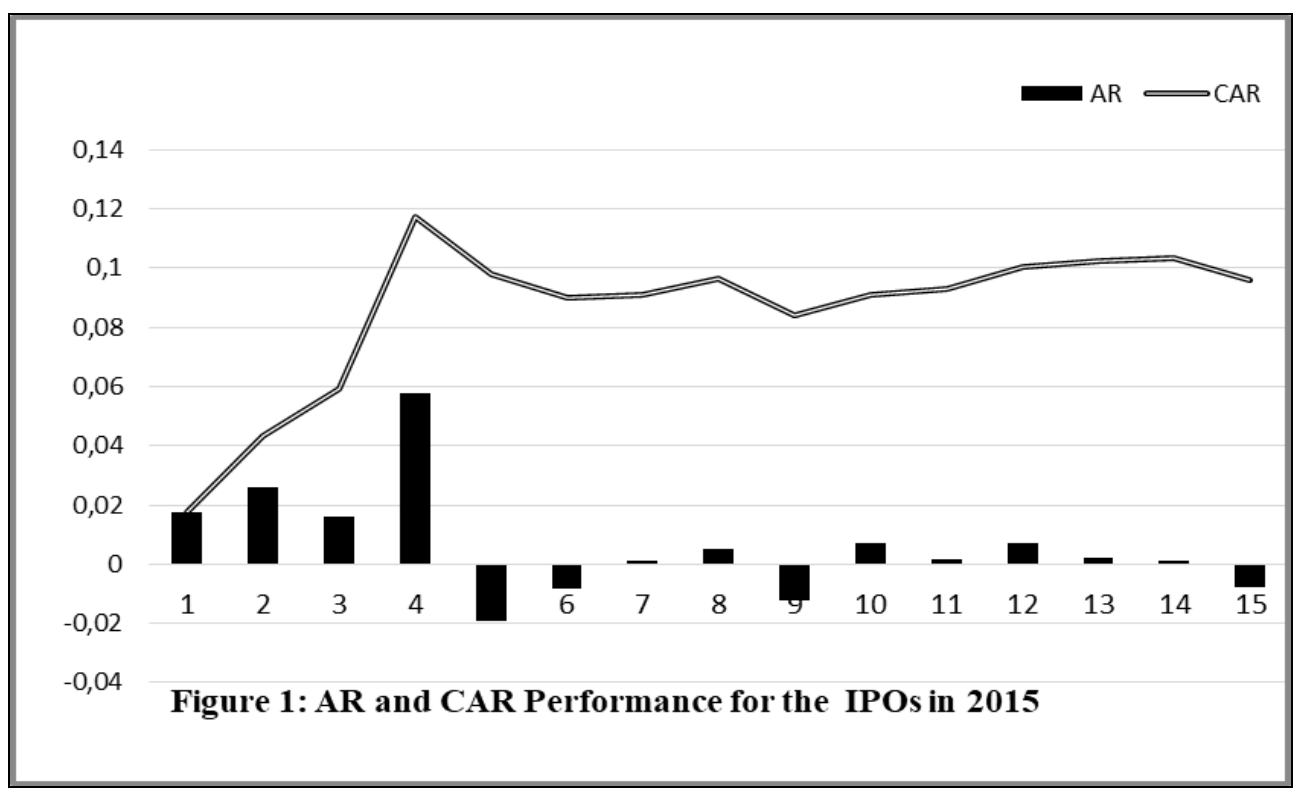

\section{Conclusion}

Since the 1970s, studies on stock market anomalies have intensified, and among those, there have been many studies carried out primarily on the underprice effect in IPOs. These studies have shown that the underpricing effect is seen more strongly in hot markets. The current study investigated the underpricing anomaly in Borsa Istanbul. It tested the hypothesis on the underpricing of small firm which is reported by Ibbotson et al. (1994) in hot and cold markets. Moreover, in the framework of the sequential learning, informational externality and industry concentration hypothesis and the demand for capital hypothesis, the anomaly of underpricing have been tested and searched if industry intensification in public offerings of firms to hot markets. Lastly, under the framework of the Market Timing and Investor Sentiment Hypothesis which links the underpricing effect of IPO to overconfidence and the self-attribution bias of investors, the performance of investors had been evaluated during the high and low confidence index periods.

The study specifically focuses on the performance of IPOs aftermath 2008 crisis when the markets are very volatile and searches to report the recent behavior trends of the investors in the market. The findings support the previous publication and 
reveal that the underpricing phenomenon prevails in the Turkish equity market after 2008. The AR and CAR values are definite with a high significance level. On the other hand, in terms of hot and cold market segmentation, the AR and CAR values are still definite in both of the markets. However, the results of a hot market for AR and CAR values are significant at most of the days. On the other hand only a few days are substantial in cold markets. This evidence underlines the underprice anomaly of the hot market, but doesn't indicate an obvious conclusion on differentiation between markets.

When the low price effect in hot and cold markets was evaluated in terms of firm size, it was seen that the underpricing anomaly is quite evident in both hot and cold markets. However, this phenomenon is more pronounced in hot markets. These findings eliminate the possibility of underpricing anomalies as international investors tend to large and reputable companies within the framework of Asymmetric Information and Signalling Hypothesis. This result supports the reports of Ibbotson et al. (1994) and M'kombe and Ward (2002). This finding can be due to the anomaly known as small firm effect (Chalk, Peavy 1987).

In our study, the consumer confidence index is in parallel with the hot markets, but it is explored that there is a much more stronger underpricing effect in periods when consumer confidence is relatively high. The result is consistent with the findings of Cornelli et al. (2006) and Oehler et al. (2004). The evidence reveals the underprice anomaly of optimistic and hot markets, moreover points out the differentiation between markets. Finally, the sequential learning, informational externality, and industry concentration hypothesis and the demand for capital hypothesis, which suggests that there may be an underpricing effect due to industrial concentration in hot markets, have been searched, but no evidence has been found.

In further studies, the relationship between the characteristics of the companies and IPO performance can be investigated, and the findings can be exciting. As firm characteristics, variables such as financial performance, firm age and region and corporate governance may be included as well.

This study will not only present new information to Borsa Istanbul companies, but will also attract the attention of investors and policymakers. Since the results of this study reveal the short-term performances in the initial public offerings, it is 


\section{Ezgi TUNCAY, Mehmet KARAN, Eren MISKI AYDIN}

essential for the time planning of the companies that will go public in Borsa Istanbul. On the other hand, it provides crucial information to individual and institutional investors who want to invest in these companies. This study also provides useful findings to the regulatory institutions of the capital markets. These organizations need to consider the performance of public offerings when evaluating issues such as market manipulation and insider trading.

\section{References}

Açikgöz Ş., Gökkaya V. (2017), The variability of IPO initial returns in Turkey, "Ege Academic Review", vol. 17 no. 1, pp. 33-58.

Agathee U.S., Brooks C., Sannassee R.V. (2012), Hot and cold IPO markets. The case of the stock exchange of Mauritius, "Journal of Multinational Financial Management", vol. 22 no. 4, pp. 168-192.

Allen F., Faulhaber G.R. (1989), Signalling by underpricing in the IPO market, "Journal of Financial Economics", vol. 23, no. 2, pp. 303-323.

Baker M., Wurgler J. (2000), The equity share in new issues and aggregate stock returns. "The Journal of Finance", vol. 55 no. 5, pp. 2219-2257.

Bayram V. (2015), Short and long run performance of initial public offerings in Turkey, PhD Thesis, Istanbul.

Baron D.P. (1982), A model of the demand for investment banking advising and distribution services for new issues, "The Journal of Finance", vol. 37 no. 4, pp. 955-976.

Bildik R., Yilmaz M.K. (2006), The market performance of initial public offerings in the Istanbul Stock Exchange,

https://pdfs.semanticscholar.org/0ccb/5e5d521c341101cb4e4dd97e6e34a39be0a2.pdf?_ga=2.13131438 $3.1331677726 .1587832674-1350871664.1587832674$ [25.04.2020].

Brown G.W., Cliff M.T. (2004), Investor sentiment and the near-term stock market, "Journal of Empirical Finance", vol. 11 no. 1, pp. 1-27.

Chalk A.J., Peavy III J.W. (1987), Initial public offerings. Daily returns, offering types and the price effect, "Financial Analysts Journal”, vol. 43 no. 5, pp. 65-69.

Chen S.S. (2011), Lack of consumer confidence and stock returns, "Journal of Empirical Finance", vol. 18 no. 2 , pp. $225-236$.

Cornelli F., Goldreich D., Ljungqvist A. (2006), Investor sentiment and pre-IPO markets, "The Journal of Finance", vol. 61 no. 3, pp. 1187-1216.

Çakır N., Küçükkocaoğlu G., Kapucu H. (2017), Initial Public Offerings in hot and cold markets, "International Journal of Economics and Administrative Studies", online ISSN 1307-9859, pp. 695708. 


\section{UNDERPRICING OF INITIAL PUBLIC OFFERINGS IN HOT AND COLD MARKETS}

Dahlquist M., Robertsson G. (2001), Direct foreign ownership, institutional investors, and firm characteristics, "Journal of Financial Economics", vol. 59 no. 3, pp. 413-440.

Daniel K., Hirshleifer D., Subrahmanyam A. (1998), Investor psychology and security market under and overreactions, "The Journal of Finance", vol. 53 no. 6, pp. 1839-1885.

Derrien F., (2005), IPO pricing in hot market conditions. Who leaves money on the table?, "The Journal of Finance", vol. 60 no. 1, pp. 487-521.

Elmas B., Amanianganeh M. (2013), Analysis of the variables which can affect low pricing anomaly in companies subject to public offering in BIST: 1995-2010 period, Afyon Kocatepe Üniversitesi, İIBF Dergisi, C. XV, S. II.

Fama E., French K. (1993), Common risk factors in the return on stocks and bonds, "Journal of Financial Economics", vol. 33 no. 1, pp. 3-56.

Fisher K.L., Statman M. (2003), Consumer confidence and stock returns, "The Journal of Portfolio Management”, vol. 30 no. 1, pp. 115-127.

Helwege J., Liang N. (2004), Initial Public Offerings in hot and cold markets, "Journal of Financial and Quantitative Analysis", vol. 39 no. 3, pp. 541-569.

Hoffman A.O., Post T. (2014), Self-attribution bias in consumer financial decision-making. How investment returns affect individuals' belief in skill, "Journal of Behavioral and Experimental Economics", vol. 52, pp. 23-28.

Ibbotson R.G., Sindelar J.L., Ritter J.R. (1994), The market's problems with the pricing of initial public offerings, "Journal of Applied Corporate Finance", vol. 7 no. 1, pp. 66-74.

Ibbotson R.G., Jaffe J.F. (1975), Hot issue markets, “The Journal of Finance”, vol. 30 no. 4, pp. 10271042 .

Jansen W.J., Nahuis N.J. (2003), The stock market and consumer confidence. European evidence, "Economics Letters", vol. 79 no. 1, pp. 89-98.

Jenkinson T., Ljungqvist A. (2001), The role of hostile stakes in German corporate governance, "Journal of Corporate Finance", vol. 7 no. 4, pp. 397-446.

Kahneman D., Slovic S.P., Tversky A. (1982), Judgment under uncertainty. Heuristics and biases, Cambridge University Press, Cambridge - New York.

Kang J.K. (1997), Why is there a home bias? An analysis of foreign portfolio equity ownership in Japan, "Journal of Financial Economics", vol. 46 no. 1, pp. 3-28.

Katti S., Phani B.V. (2016), Underpricing of initial public offerings: a literature review, "Universal Journal of Accounting and Finance”, vol. 4 no. 2, pp. 35-52.

Keim D.B. (2008), Financial market anomalies, in: The new Palgrave dictionary of economics, Palgrave Macmillan, London. 


\section{Ezgi TUNCAY, Mehmet KARAN, Eren MISKI AYDIN}

Ljungqvist A., Nanda V., Singh R. (2006), Hot markets, investor sentiment, and IPO pricing, "The University of Chicago Press Journals", vol. 79 no. 4, pp. 1667-1702.

Lakonishok J., Shleifer A., Vishny R.W. (1994), Contrarian investment, extrapolation, and risk, “The Journal of Finance", vol. 49 no. 5, pp. 1541-1578.

Lee C.M., Shleifer A., Thaler R.H. (1991), Investor sentiment and the closed-end fund puzzle, "The Journal of Finance", vol. 46, no. 1, pp. 75-109.

McLean D., Pontiff J. (2016), Does academic research destroy return predictability?, "The Journal of Finance", vol. 71 no. 1, pp. 5-32.

M'kombe C., Ward M. (2002), Aftermarket price performance of initial public offerings on the JSE, "Investment Analysts Journal", vol. 31 no. 5, pp. 7-20.

Merikas A., Gounopoulos D., Nounis C. (2009), Global shipping IPOs performance, "Maritime Policy \& Management", vol. 36 no. 6, pp. 481-505.

Muscarella C.J., Vetsuypens M.R. (1989), A simple test of Baron's model of IPO underpricing, "Journal of Financial Economics", vol. 24 no. 1, pp. 125-135.

Novy-Marx R., Velikow M. (2015), A taxonomy of anomalies and their trading costs, "The Review of Financial Studies", vol. 29 no. 1, pp. 104-147.

Oehler A., Rummer M., Smith P.N. (2005), IPO pricing and the relative importance of investor sentiment. Evidence from "SSRN" https://poseidon01.ssrn.com/delivery.php?ID=152013104065025064091085068026026102101074051 04200706012608802809012209612700507507305502002909712112602012408100511112600606200 70280640351140770060230980210980210260851210700721220250060790050690800691150271251 $27096115104095119093078115110081105 \& E X T=\operatorname{pdf}[24.04 .2020]$.

Otoo M.W. (1999), Consumer sentiment and the stock market, Board of Governors of the Federal Reserve System, https://www.federalreserve.gov/Pubs/feds/1999/199960/199960pap.pdf [27.01.2020].

Persons J.C., Warther V.A. (1997), Boom and bust patterns in the adoption of financial innovations, "The Review of Financial Studies", vol. 10 no. 4, pp. 939-968.

Reilly F.K., Hatfield K. (1969), Investor experience with new stock issues, "Financial Analysts Journal", vol. 25 no. 5, pp. 73-80.

Ritter J.R. (1984), The hot issue market of 1980, “Journal of Business”, vol. 57 no. 2, pp. 215-240.

Ritter J.R. (1991), The long-run performance of Initial Public Offerings, "The Journal of Finance", vol. 46 no. 1, pp. 3-27.

Ritter J.R., Welch I. (2002), A review of IPO activity, pricing, and allocations, "The Journal of Finance", vol. 57 no. 4, pp. 1795-1828.

Rock K. (1986), Why new issues are underpriced, "Journal of Financial Economics", vol. 15 no. 1-2, pp. 187-212. 


\section{UNDERPRICING OF INITIAL PUBLIC OFFERINGS IN HOT AND COLD MARKETS}

Stoughton N., Wong K.P., Zechner J. (2001), IPOs and product quality, “The Journal of Business", vol. 74 no. 3 , pp. $375-408$.

Subrahmanyam A., Titman S. (1999), The going public decision and the development of financial markets, "The Journal of Finance", vol. 54 no. 3, pp. 1045-1082.

Van Heerden G., Alagidede P. (2012), Short run underpricing of initial public offerings (IPOs) in the Johannesburg Stock Exchange (JSE), "Review of Development Finance", vol. 2 no. 3-4, pp. 130-138.

Welch I. (1989), Seasoned offerings, imitation costs, and the underpricing of initial public offerings, "The Journal of Finance", vol. 44 no. 2, pp. 421-449. 